\title{
Os historiadores, de Veronique Sales
}

\author{
Giuliano Lellis Ito Santos ${ }^{1}$
}

\section{$r$}

emos em mãos um livro que apresenta um panorama sobre a historiografia contemporânea, demonstrando como o campo dessa disciplina se modificou nos dois últimos séculos. A singularidade da vida e da obra de dezenove historiadores é aqui contemplada com textos instigantes que nos estimulam a ler os seus trabalhos, indicados ao final de cada capítulo.

O livro, publicado pela Editora da Unesp em 2011, com tradução de Christiane Gradvohl Colas, está organizado em dezenove capítulos, cada qual tratando de um historiador, ou algum pensador que tenha contribuído para a reflexão sobre a História. Cada um desses capítulos é escrito por um especialista, que realiza uma reflexão consistente sobre o autor tratado. Dessa forma, se tivermos em vista o apontamento da organizadora de que "o historiador, então, revela de seu tempo tanto quanto experimenta ressuscitar ou recriar o de outro [...]: cada historiador fala de si mesmo tanto quanto daquele povo de mortos" (SALES, 2011, p. 7). Cada leitura expõe a obra de um autor e põe em relevo uma reflexão contemporânea sobre a História.

A organização do livro é creditada a Véronique Sales, colaboradora de L'Histoire (uma revista nos moldes de A História Viva) e romancista, autora de Le livre de Pacha, La vie, simples e tranquille e Trois rêves d'Éphrä̈m. Ainda como colaboradores dessa mesma revista, fazem parte do volume François Lebrun e Maurice Sartre, que assinam um capítulo cada. Além disso, figuram nos títulos dos capítulos outros nomes que também colaboraram para a referida revista, como Georges Duby, François Furet e Jacques Le Goff.

1 Doutor em Literatura Portuguesa pela FFLCH-USP. 
Apesar de apresentar os historiadores na ordem cronológica, a organizadora observa que seu propósito não é o de" provar que a História é apenas subjetiva e evolutiva, que a obra de um historiador começa onde termina a que precedeu" (SALES, 2011, p.8). Conforme seguimos a leitura, de fato percebemos as relações entre os métodos e as reflexões sobre a História, e que essas relações nem sempre são lineares. Outro ponto a se destacar é a escolha dos nomes que figuram no volume, questão problematizada pela organizadora, que afirma já esperar as críticas por lembrar-se de uns e esquecer outros. Ainda sobre esse tópico, nota que "seu objetivo é deixar desenvolver-se o propósito, o discurso do método de cada um dos autores apresentados" (SALES, 2011, p. 8).

Tendo em mente o objetivo do livro - situar a obra de cada historiador em seu tempo, sem perder de vista a dupla temporalidade dos textos, em que cada historiador ao falar de outro fala também de si mesmo -, podemos ter uma ideia de como o pensamento da História se modificou ao longo de dois séculos, além de termos a oportunidade de vislumbrarmos as transformações dentro desse campo do saber, acima de tudo, vemos como alguns de seus conceitos essenciais têm suas bases repensadas.

A escrita da história sempre esteve ligada a narrativa, seja pelo seu emprego como meio de recompor o passado seja pela negação de sua eficiência. Nesse sentido, podemos notar que a narrativa histórica de Michelet surge, no livro, como a precursora das discussões sobre a pesquisa e a consolidação da História como ciência durante o século XIX e XX. Dessa forma, no primeiro capítulo vemos apresentadas as principais linhas que serão pensadas e repensadas pelos outros nomes, algumas vezes mudando a abordagem, outras o método. Michelet traz para a história a mania do arquivo, a pesquisa incansável, a análise dos documentos, mas junto com isso traz também uma narrativa quase romanesca, uma ordenação cronológica e baseada nos "fatos". Todas essas questões são retomadas durante a apresentação de outros historiadores incluídos no livro.

Segundo se depreende da leitura do livro, alguns pontos importantes constituem o campo da História na contemporaneidade: a pesquisa documental, a organização dos documentos e a transposição dessa pesquisa para a forma escrita. É interessante notar como a École des Annales informa todo o volume. Surgido no início do século XX, movimento historiográfico constituído em torno do periódico Annales d'Histoire Économique et Sociale, fundado por Lucien Febvre e March Bloch em 1929. Febvre, considerando que "o objeto 
histórico é visto como estruturalmente complexo" (SALES, 2011, p. 66), julga que o historiador deve "se debruçar sobre o que se disse e o que se diz ainda do passado com desconfiança” (SALES, 2011, p. 66), como afirma Denis Crouzet, que assina o capítulo sobre esse historiador. Esse posicionamento produz uma escrita que "é difícil, às vezes quase desprazerosa, a ponto de poder levar o leitor a se perguntar aonde ele pretende chegar com tantos desvios" (SALES, 2011, p. 67). Assim, vemos que ao repensar o posicionamento diante da pesquisa, o historiador acaba por modificar a sua forma de escrita. Isso quer dizer que, conforme os historiadores refletem sobre o objeto e sua abordagem, torna-se imprescindível repensarem a forma como vão organizar e relatar seu trabalho. Nesse caso, ao contrário da ressuscitação do passado, como pretendido por Michelet, Febvre tem um posicionamento mais distanciado do documento, que o conduz ao caminho da diferenciação entre o passado sólido e os indícios que servem para recompô-lo.

$\mathrm{Na}$ segunda geração dos Annales, fica mais clara a mudança. Dessa maneira, quando Fernand Braudel opõe história factual e história profunda, temos uma reflexão sobre o espaço e o tempo pautado na mentalidade da época, ou, como apontado por ele mesmo: "Entendo dessa maneira, com alguns historiadores de hoje e de ontem, uma história dos homens vista em suas realidades coletivas, na evolução lenta das estruturas conforme uma palavra em moda atualmente: estrutura dos Estados, das economias, das sociedades e das civilizações" (SALES, 2011, p. 162).

A proposta de buscar na transformação lenta das sociedades a explicação do passado leva o historiador a centrar-se no espaço, pautado na geografia e na sociologia, como melhor forma de recompor, de certa maneira, uma totalidade desse passado, questão que deságua na proposição de uma história global.

$\mathrm{Na}$ terceira geração, com a Nova História, destaca-se o nome de Jacques Le Goff, que vai buscar a globalidade dos processos históricos, "em que os acontecimentos políticos constituem apenas um aspecto visível" (SALES, 2011, p. 296), como nota Alain Boureau. Dessa forma, Le Goff vai atrás de fontes ignoradas por outros historiadores como, por exemplo, os textos literários, os relatos hagiográficos etc. Com a inclusão de gêneros desprezados pela História, Le Goff aponta para uma visão global da história medieval, já que sua pesquisa vai além do visível, do econômico, do político, o que já havia sido esboçado na obra de Fernand Braudel. 
Além desse percurso pelos historiadores da École des Annales, vale a pena destacar um nome que não faz parte desse grupo: Louis Robert, historiador cujo domínio era o mundo grego antigo. Ainda que fosse "ignorado pelo público", sua obra imensa teve impacto considerável nos estudos das inscrições. Devido ao seu "domínio perfeito do grego antigo (e do latim, claro)", ele apresentou um método pautado no exame escrupuloso do texto. Isso leva Maurice Sartre, autor do capítulo sobre o historiador, a observar que: "a autoridade de Louis Robert, assim como seu método, baseia-se, em primeiro lugar, nessa capacidade excepcional em estabelecer textos certos, em eliminar restabelecimentos falsos ou até duvidosos. O rigor demonstrado na matéria serviu de modelo a gerações de epigrafistas" (SALES, 2011, p. 193). Nesse exemplo, vemos como o estudo das inscrições antigas, baseado no domínio das línguas, leva a uma nova abordagem, colaborando para uma releitura do passado.

Ainda sobre o mundo antigo podemos destacar os estudos de Paul Veyne, que é caracterizado como inapreensível e imprevisível. O caminho escolhido por ele é bem diferente do de Louis Robert, pois seu foco é o de refletir sobre a escrita, a epistemologia e a pesquisa históricas. De sua reflexão resulta que a História não serve para estabelecer leis, pois seu domínio é "do vivido, dos feitos humanos" (SALES, 2011, p. 358), como ressaltado por Patrick Le Roux. A história, segundo Veyne, "é uma história verdadeira e 'completa', o que não quer dizer portadora de verdade nem de totalidade" (SALES, 2011, p. 358). Essa ideia leva à conjectura de que "os feitos humanos não se reduzem aos acontecimentos políticos, mas englobam todos os feitos não factuais que convém fazer aceder à historicidade” (SALES, 2011, p. 358). Dessa forma, ao contrário da visão micheletiana de fazer falar os mortos, Paul Veyne propõe que "um historiador não faz os romanos falarem... ele fala no lugar deles..." (SALES, 2011, p. 359). Assim quando um historiador se debruça sobre uma sociedade ele compartilha os desconhecimentos e as ilusões que as sociedades do passado têm de si próprias. Nesse caso, estamos diante de um posicionamento diferencial do passado, ou seja, o passado é irresoluto no presente, seus indícios não são suficientes para recompô-lo, mas o que resta é a totalidade que temos dele.

Por fim, o livro traz um elenco bastante eficiente para conhecermos brevemente os pontos nodais das modificações da História ao longo dos séculos XIX e XX. Ao seguirmos os capítulos temos uma ideia de como a pesquisa 
histórica tende a utilizar materiais diferentes nas suas abordagens, sendo que um dos materiais que passa a ter importância para os historiadores é o texto literário. A literatura ganha espaço na recomposição do passado, registrando o que outro tipo de documento não registraria, e ganha lugar na história da própria escrita, ou da importância da escrita nas sociedades. Essa abordagem nos coloca diante da questão espinhosa que é a diferenciação entre ficção e História, já que, cada vez mais, segundo a leitura do livro, a escrita imaginativa passa a fazer parte dos documentos de que se servem os historiadores para entenderem o passado, além de revelar que o modo como o historiador compõe a história guarda um vínculo com a invenção e a imaginação.

Recebido em 07/03/2011 e aprovado em 10/04/2011. 